\title{
Assessment of adrenal reserve and secretion of cortisol in patients over 60 years of age undergoing cardiac surgery
}

\author{
Magda L Piekarska ${ }^{1,2}$, Marta Buda3 ${ }^{3}$ Marek A. Deja ${ }^{1,2}$ \\ ${ }^{1}$ Department of Cardiac Surgery, School of Medicine in Katowice, Medical University of Silesia, Katowice, \\ Poland \\ ${ }^{2}$ Department of Cardiac Surgery, Upper Silesian Heart Center, Katowice, Poland \\ ${ }^{3}$ Student, Medical University of Silesia, Katowice, Poland
}

Kardiochir Torakochir Pol 2019; 16 (3): 118-123

\begin{abstract}
Introduction: Cortisol level affects the prognosis of patients after cardiac surgery. Meanwhile, there are no clear guidelines for steroid supplementation after a cardiac operation. The relationship between age and blood cortisol levels has not been finally clarified.

Aim: Assessment of adrenal reserve and secretion of cortisol in patients over 60 years of age undergoing cardiac surgery. Material and methods: The study included 20 patients of both sexes referred for cardiac surgery. A short ACTH synthetic stimulation test was carried out. Assessment of cortisol secretion was carried out in the morning on the day of surgery and the $1^{\text {st }}, 2^{\text {nd }}$ and $4^{\text {th }}$ days after surgery in blood samples.

Results: A result within the normal range for the adrenal reserve was found in 19 of the 20 patients enrolled in the study. The short Synacthen test predicted postoperative secretion of cortisol $(p=0.04, r=0.047)$. A relationship between secretion of cortisol and patients' age was observed ( $p=0.03$, $r=0.48)$. The concentration of cortisol on the $1^{\text {st }}$ postoperative day was correlated with the total dose of dopamine ( $p=0.006$, $r=0.58)$ and adrenaline $(p=0.04, r=0.47)$. The concentration of cortisol on the day of the surgery correlated with the lactate concentration on day $2(p=0.04, r=0.45)$. The concentration of lactates on day 1 correlated with total dose of dopamine $(p=0.01, r=0.54)$.

Conclusions: A short Synacthen test allows one to predict secretion of cortisol after cardiac surgery. Greater secretion of cortisol after cardiac surgery may be associated with a more difficult postoperative course. There was no decrease in cortisol secretion with age.
\end{abstract}

Key words: cardiac surgery, cortisol, ACTH stimulation test.

\section{Streszczenie}

Wprowadzenie: Pooperacyjne stężenie kortyzolu wpływa na przebieg pooperacyjny i rokowanie pacjentów po operacjach kardiochirurgicznych. Nie istnieją jasne wytyczne dotyczące suplementacji glikokortykosteroidami po operacjach kardiochirurgicznych. Nie wyjaśniono także ostatecznie związku między wiekiem a stężeniem kortyzolu we krwi.

Cel: Ocena rezerwy nadnerczowej oraz wydzielania kortyzolu u pacjentów w wieku powyżej 60 lat poddawanych operacjom kardiochirurgicznym.

Materiał i metody: Do badania włączono 20 pacjentów obojga płci w wieku powyżej 60 lat spełniających kryteria badania. U pacjentów przeprowadzono skrócony test stymulacji syntetycznym ACTH: oznaczano stężenie kortyzolu we krwi - wyjściowo, w 30. i 60. minucie po podaniu $250 \mu \mathrm{g}$ Synacthenu domięśniowo. W celu oceny wydzielania kortyzolu oznaczano jego stężenie rano między godziną 8.00 a 10.00 w dniu operacji, a także w 1., 2. i 4. dobie od zabiegu w próbkach krwi.

Wyniki: Wynik w granicach normy dla rezerwy nadnerczowej stwierdzono u 19 spośród 20 pacjentów włączonych do badania. Test z Synacthenem pozwalał przewidywać pooperacyjne wydzielanie kortyzolu ( $p=0,04, r=0,047)$. Stwierdzono związek między wydzielaniem kortyzolu a wiekiem pacjentów $(p=0,03$, $r=0,48)$. Stężenie kortyzolu $w 1$. dobie korelowało z całkowitą dawką dopaminy $(p=0,006, r=0,58)$ i adrenaliny $(p=0,04$, $r=0,47)$. Stężenie kortyzolu $w$ dniu operacji korelowało ze stężeniem mleczanów w 2. dobie ( $p=0,04, r=0,45)$. Stężenie mleczanów w 1. dobie korelowało z całkowitą dawką dopaminy $(p=0,01, r=0,54)$. Nie stwierdzono wpływu rodzaju zabiegu, czasu krążenia pozaustrojowego i zaklemowania aorty na wydzielanie kortyzolu w okresie pooperacyjnym.

Wnioski: Skrócony test z Synacthenem pozwala przewidzieć wydzielanie kortyzolu po operacji kardiochirurgicznej. Większe wydzielanie kortyzolu po operacji kardiochirurgicznej może być związane z trudniejszym przebiegiem pooperacyjnym. Nie obserwowano zmniejszenia wydzielania kortyzolu wraz z wiekiem.

Słowa kluczowe: operacja kardiochirurgiczna, kortyzol, test z Synacthenem.

Address for correspondence: Magda L. Piekarska MD, PhD, Department of Cardiac Surgery, School of Medicine in Katowice, Medical University of Silesia, 45/47 Ziołowa St, 40-635 Katowice, Poland, phone: +48 530278 576, e-mail: magdalucynapiekarska@gmail.com Received: 4.06.2019, accepted: 20.09.2019. 


\section{Introduction}

The basic mechanism in response to stress, especially surgical trauma, is the stimulation of the hypothalamicpituitary-adrenal axis and the increase in cortisol secretion by the adrenal glands. The plasma concentration of cortisol stays within 40-50 g/dl after a stressful situation [1]. The cortisol level is associated with prognosis - both elevated and low values (characteristic for adrenal insufficiency in response to stress) correlate with a higher mortality rate [2]. The treatment of patients with high values of cortisol has not been fully elucidated, but it is well known that the treatment of adrenal insufficiency improves the survival of patients in a severe condition, including after cardiac surgery [3].

Diagnosing adrenal insufficiency in patients after cardiac surgery is difficult. The systemic inflammatory response syndrome is manifested by low cardiac output, tachycardia and fever - symptoms that we also find in patients with adrenal insufficiency. This diagnosis is more difficult in the older population [4]. Despite numerous studies carried out on the elderly population, the relationship between cortisol secretion and age and sex of patients has not been fully explained [5, 6]. Meanwhile, this issue has important clinical implications. Further research on this topic may help to create standards for treating the older population [5].

Assessment of the adrenal reserve would enable the creation of a treatment standard after cardiac surgery and could improve the prognosis in patients with preoperatively reduced adrenal reserve. Salem's and Coursin's groups [7, 8] recommend the use of steroid supplementation in patients with known cortisol secretion disorders, depending on the type of surgery. After cardiac surgery, the minimum dose of hydrocortisone should be between 100 and $150 \mathrm{mg}$ administered for 2 to 3 postoperative days. In patients who are suspected of adrenal insufficiency a short stimulation test is recommended. Patients with suspected or diagnosed adrenal disease subjected to steroid supplementation undergo surgical procedures with better outcomes. The experience of Raja et al. suggests that older patients after cardiac surgery with possible adrenal gland disorders require extended use of hydrocortisone supplementation [9]. The standard has not been developed in this topic.

\section{Aim}

The aim of the study was assessment of adrenal reserve and secretion of cortisol in patients over 60 years of age undergoing cardiac surgery.

\section{Material and methods}

The study involved 20 consecutive patients of both sexes, aged over 60 who were referred for cardiac surgery. The study was performed at the Department of Cardiac Surgery, Upper-Silesian Heart Center, Medical University of Silesia in Katowice, Poland.

The study was approved by the Institutional Review Board of the Medical University of Silesia, Katowice, Poland
(Nr KNW/0022/KB1/74/II/15/16/17). Exclusion criteria were as follows: endocrine disease, therapy with steroids during the 6 months before the surgery, addiction to alcohol or drugs, previous cardiac surgery, diseases of the central nervous system.

After receiving written consent, a short ACTH stimulation test was carried out: blood levels of cortisol were measured at 30 and 60 minutes after administration of $250 \mu \mathrm{g}$ of Synacthen intramuscularly. Assessment of cortisol secretion was carried out in the morning between 8.00 and $10.00 \mathrm{am}$ - on the day of surgery, on the first day, on the $2^{\text {nd }}$ day and on the fourth day after surgery in blood samples by the electrochemiluminescence method (ECLIA, Elecsys Cortisol II).

The total dose of inotropic drugs (dopamine, norepinephrine, epinephrine) used in every patient was evaluated. Lactate concentration was determined as the mean value of measurements taken every 2 hours during the $1^{\text {st }}$ and $2^{\text {nd }}$ days after surgery.

\section{Statistical analysis}

Descriptive statistics were summarized by means and standard deviation as well as frequencies (\%) as appropriate. The cross-clamping time, cardiopulmonary bypass time and duration of surgery were presented as median and divided into quartiles. The Shapiro-Wilk test was used for the assessment of normal distribution. The quantitative data were compared with Student's t-test if normally or log-normally distributed (log-transformed as appropriate). Quantitative data not having a normal distribution were compared by the Mann-Whitney $U$-test for independent groups. Categorical data were compared between groups with Fisher's exact test. Qualitative data and quantitative data that did not have a normal distribution for dependent groups were compared by the Wilcoxon pairs order test.

\section{Results}

Twenty patients over 60 years of age were included in the study. The group was $85 \%$ male. The average age was 69 years. The characteristics of the studied population are presented in Table I. The patients underwent cardiac surgery; $75 \%$ of them had coronary artery bypass grafting. The median aortic cross-clamping time was 30.5 (interquartile range-Q1; Q3 - 24; 52) minutes. The median cardiopulmonary bypass time was $58(45.5 ; 75.2)$ minutes. Perioperative data are presented in Table II. There were noted 21 adverse events (Figure 1). The most frequent in the study group was the necessity to transfuse blood and blood products (35\%), then atrial fibrillation (20\%) (Figure 1).

The assessment of the adrenal reserve using the Synacthen test was positive in 19 of the 20 patients enrolled in the study. The mean initial cortisol concentration was 7.5 $\pm 3.1 \mathrm{mg} / \mathrm{dl}$ and increased at $30 \mathrm{~min}$ after Synacthen injection to $23.3 \pm 5.0 \mathrm{mg} / \mathrm{dl}$ and increased at 60 minutes to 28.0 $\pm 5.8 \mathrm{mg} / \mathrm{dl}$ (Figure $2 \mathrm{~A}$ ). The mean preoperative morning cortisol concentration was $12.4 \pm 3.95 \mathrm{mg} / \mathrm{dl}$ and increased on the first postoperative morning to $21.1 \pm 9.0 \mathrm{mg} / \mathrm{dl}$ (Fig- 
Table I. Characteristics of study population

\begin{tabular}{|c|c|}
\hline Parameter & $\begin{array}{c}\text { SD or } \% \\
N(\%)\end{array}$ \\
\hline Age [years] & $69 \pm 7.4$ \\
\hline Sex (male) & $17(85)$ \\
\hline Weight [kg] & $82 \pm 11.7$ \\
\hline \multicolumn{2}{|l|}{$\mathrm{BMI}\left[\mathrm{kg} / \mathrm{m}^{2}\right]$} \\
\hline \multicolumn{2}{|l|}{$\mathrm{BSA}\left[\mathrm{m}^{2}\right]$} \\
\hline EF (\%) & $47 \pm 12$ \\
\hline \multicolumn{2}{|l|}{ CCS class: } \\
\hline 1 & $8(40)$ \\
\hline II & $8(40)$ \\
\hline III & $4(20)$ \\
\hline \multicolumn{2}{|l|}{ NYHA class: } \\
\hline 1 & $1(5)$ \\
\hline$\underline{\|}$ & $19(95)$ \\
\hline III-IV & 0 \\
\hline Previous MI & $11(55)$ \\
\hline Previous stroke & $1(5)$ \\
\hline Previous PCl & $4(20)$ \\
\hline Smokers & $2(10)$ \\
\hline Past smokers & $15(75)$ \\
\hline Arterial hypertension & $20(100)$ \\
\hline \multicolumn{2}{|c|}{ Medication at time of hospital admission: } \\
\hline ACE inh/ARBs & $17(85)$ \\
\hline$\beta$-Blockers & $17(85)$ \\
\hline $\mathrm{CCB}$ & $4(20)$ \\
\hline Spironolactone & $3(15)$ \\
\hline Loop diuretics & $10(50)$ \\
\hline Aspirin & $20(100)$ \\
\hline Statins & $18(90)$ \\
\hline Amiodarone & $2(10)$ \\
\hline Nitrate & $2(10)$ \\
\hline EuroSCORE II (\%) & $2.35 \pm 1.67$ \\
\hline
\end{tabular}

$\mathrm{BMI}$ - body mass index, BSA - body surface area, EF - ejection fraction, CCS class - Canadian Cardiovascular Society class, NYHA class - New York Heart Association Functional Classification, $\mathrm{MI}$ - myocardial infarction,

$\mathrm{PCl}$ - percutaneous coronary intervention, ACE - angiotensin-converting enzyme, ARBs - angiotensin-II-receptor blockers, CCB - calcium channel blockers, SD - standard deviation.

ure 2 B). The Synacthen test predicted postoperative secretion of cortisol in patients undergoing cardiac surgery $(p=0.04, r=0.047)$.

We found an association of cortisol secretion with the age of patients ( $p=0.03, r=0.48$ ) (Figure 3 ). The concentration of cortisol on the first postoperative day correlated with the total dose of dopamine $(p=0.006, r=0.58)$ and adrenaline $(p=0.04, r=0.47)$. The concentration of cortisol on the day of surgery correlated with the lactate concentration on day 2 ( $p=0.04, r=0.45$ ) (Figure 4). The concentration of lactates on day 1 correlated with the total dose of dopamine ( $p=0.01, r=0.54)$ (Figure 5). There was no effect of the type of surgery, cardiopulmonary bypass time or aor-
Table II. Perioperative data

\begin{tabular}{lc} 
Type of surgery & Value \\
CABG, $n(\%)$ & $15(75)$ \\
\hline Valve surgery, $n(\%)$ & $2(10)$ \\
\hline Complex operation, $n(\%)$ & $3(15)$ \\
\hline Cross-clamp time, median (Q1; Q3) [min] & $30.5(24 ; 52)$ \\
\hline Cardiopulmonary bypass time, median (Q1; Q3) & $58.0(45.5 ; 75.5)$ \\
\hline Duration of surgery, median (Q1; Q3) & $152.5(135 ; 180)$ \\
\hline
\end{tabular}

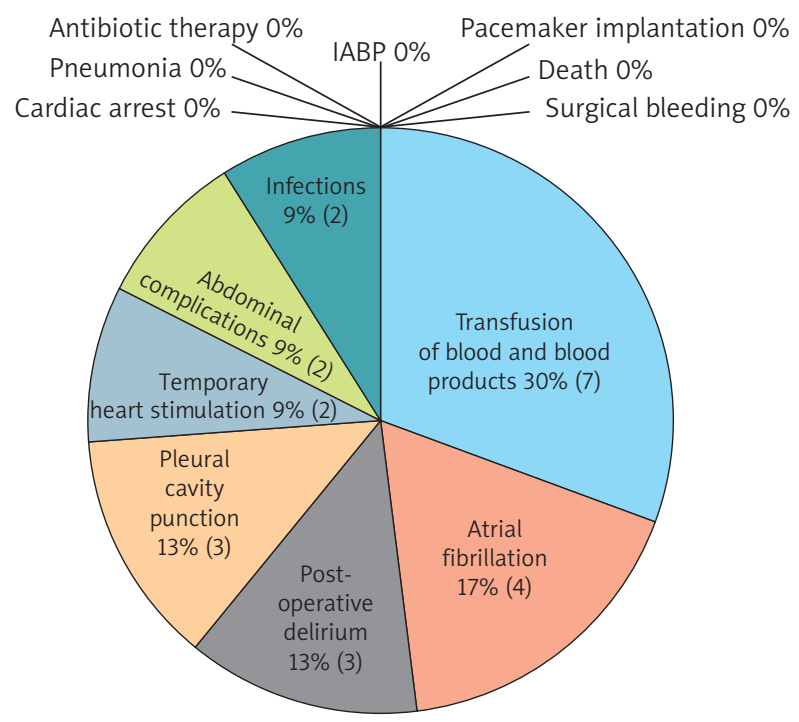

Figure 1. Adverse events

tic cross-clamping time on the secretion of cortisol in the postoperative period (Table III).

In our group, there was no strong association between the occurrence of delirium and the cortisol concentration before $(p=0.6, r=0.13)$ and after surgery $\left(1^{\text {st }}\right.$ day after operation $-p=0.06, r=0.42,2^{\text {nd }}$ day after operation $-p=0.03$, $r=0.48,4^{\text {th }}$ day after operation $-p=0.44, r=0.18$ ) and results from the Synacthen test (30 minutes after $-p=0.55$, $r=0.14,60$ minutes after $-p=0.40, r=0.2$ ).

\section{Discussion}

The cardiopulmonary bypass is an acute stress situation for human organs and tissues. It triggers activation of the hypothalamic-pituitary-adrenal axis (HPA) and induces an increase in cortisol secretion. However, about $10-20 \%$ of severely ill patients experience adrenocortical insufficiency [10]. The main symptoms of adrenocortical insufficiency are systemic inflammatory response syndrome (SIRS) and cardiovascular system dysfunctions [10]. However, in the present study, no decreased secretion of cortisol was observed in patients undergoing cardiac surgery in the postoperative period.

The cortisol concentration in patients below $9 \mu \mathrm{g} / \mathrm{dl}$ after administration of $250 \mu \mathrm{g}$ of corticotropic hormone is called relative adrenal insufficiency (RAI - relative adrenal insufficiency) [11]. It is diagnosed in seriously ill patients and 

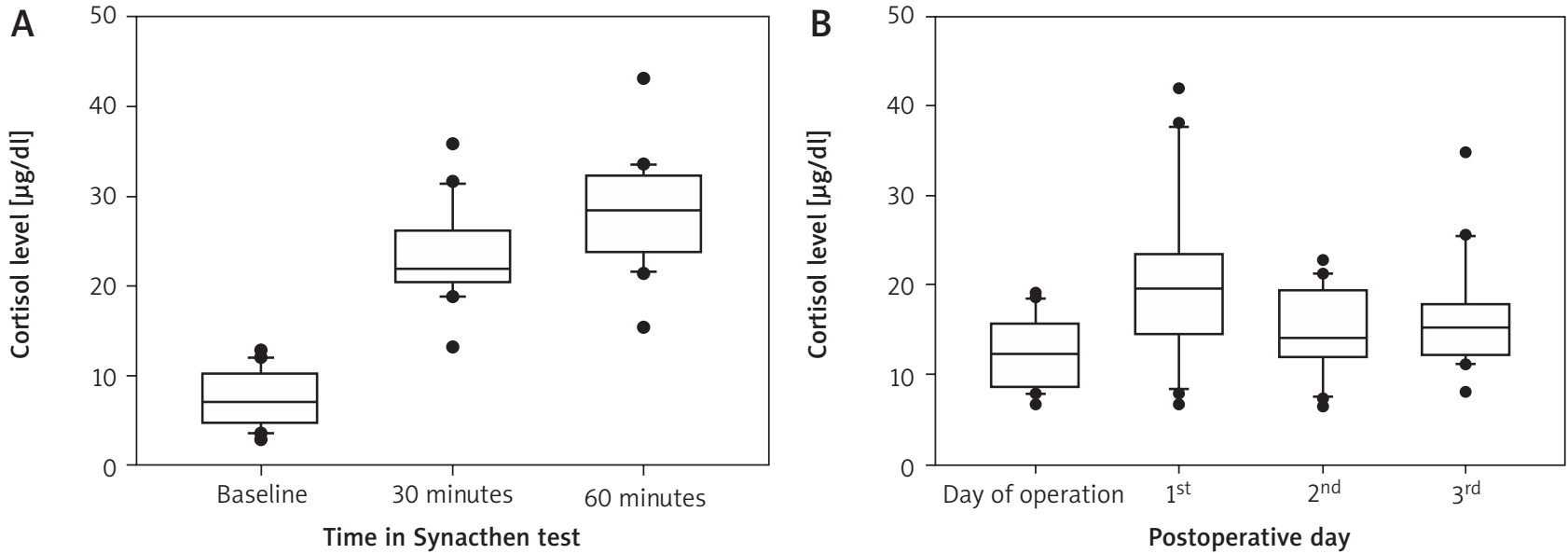

Figure 2. A - Cortisol level during Synacthen test (baseline, 30 minutes and 60 minutes after administration of Synacthen intramuscularly) (mean, standard deviation, each outliers). B - Cortisol level during peri- and postoperative period (mean, standard deviation, each outliers)

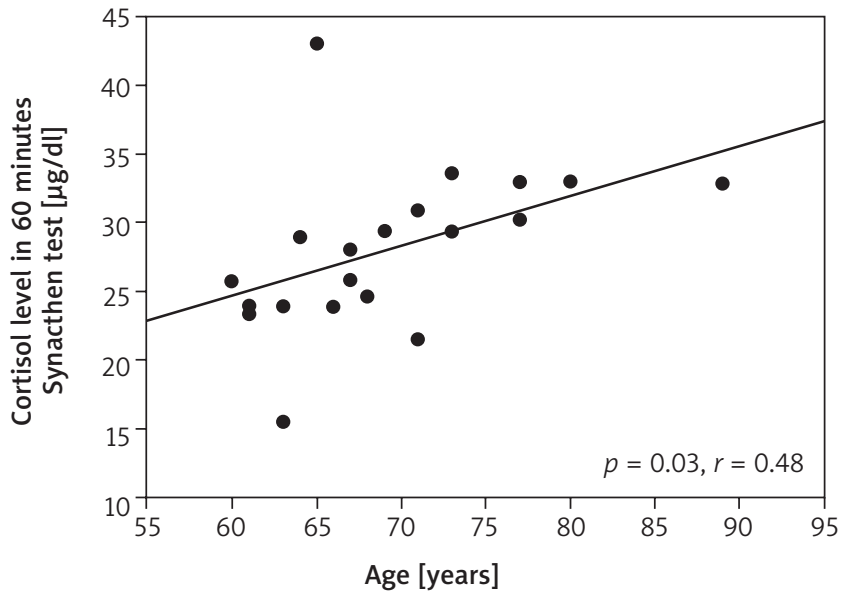

Figure 3. The assessment between cortisol level and age of patients

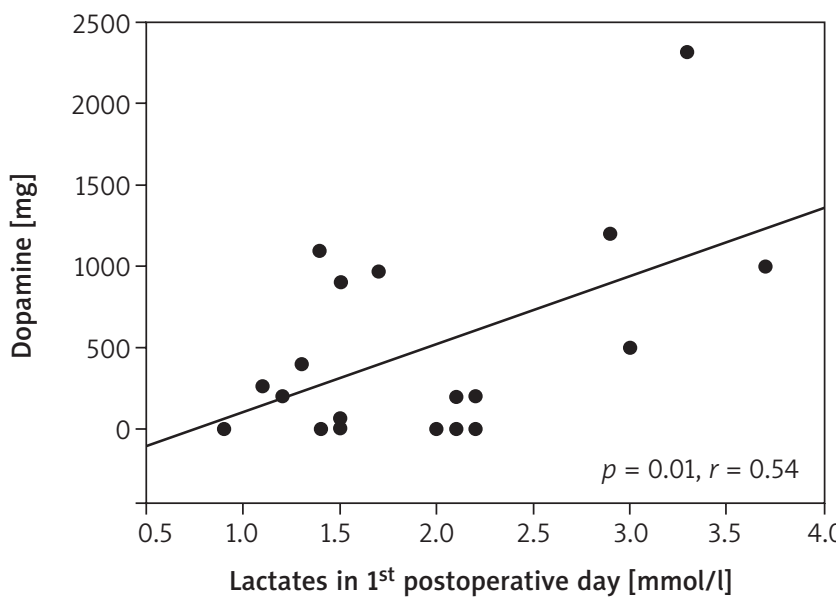

Figure 5. Correlation between total dose of dopamine and lactates on $1^{\text {st }}$ postoperative day

its presence is associated with worse prognosis in sepsis [12]. Relative adrenocortical insufficiency is recognized as inadequate cellular activity of corticosteroid hormones in seriously ill patients. Iribarren et al. diagnosed RAl in $77.5 \%$ of the group - the Synacthen test was carried out within

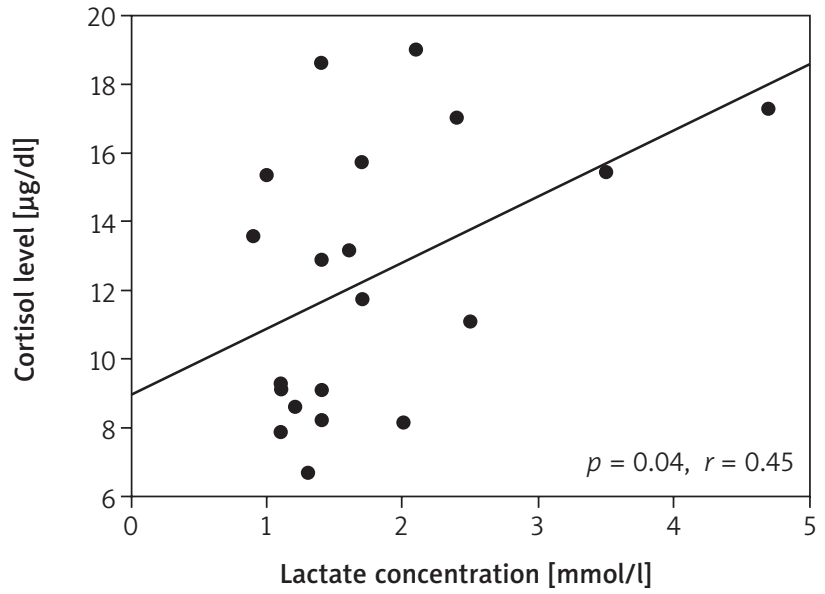

Figure 4. Correlation between cortisol level on the day of surgery and the lactate concentration on the $2^{\text {nd }}$ postoperative day

Table III. Correlation between cortisol secretion after operation and duration of surgery, cardiopulmonary bypass time and crossclamping time

\begin{tabular}{llll} 
Parameter & \multicolumn{1}{c}{$\begin{array}{c}\text { Cortisol }- \\
\text { 1POD }\end{array}$} & $\begin{array}{c}\text { Cortisol }- \\
\text { 2POD }\end{array}$ & $\begin{array}{c}\text { Cortisol - } \\
\text { 4POD }\end{array}$ \\
Duration of surgery & $p=0.21$ & $p=0.86$ & $p=0.48$ \\
& $r=0.30$ & $r=0.04$ & $r=-0.167$ \\
\hline Cardiopulmonary & $p=0.52$ & $p=0.81$ & $p=0.44$ \\
bypass time & $r=0.16$ & $r=-0.06$ & $r=-0.18$ \\
\hline Cross-clamping time & $p=0.61$ & $p=0.76$ & $p=0.37$ \\
& $r=0.16$ & $r=-0.7$ & $r=-0.21$ \\
\hline
\end{tabular}

POD - postoperative day.

4 hours of the surgery [11]. In our study, such low values of cortisol levels occurred in just one patient. However, no worse course of this patient was observed. In addition, the number of adverse events in the entire study group was low.

Cardiac surgery is a major stimulus that causes endogenous release of catecholamines and stress hormones. The onset of cardiopulmonary bypass increases the concentration of norepinephrine, epinephrine and cortisol in the blood [13]. The Hoda group showed that the cortisol concentra- 
tion is maintained at an increased level until the end of the surgery, reaching a maximum value within 4-6 hours after the operation. Then, the concentration decreases to the preoperative values within 24 hours [14]. In the present study, the decrease in cortisol concentration did not occur even on the fourth day after surgery, and the adrenal reserve assessment test was performed before the operation.

Patient anesthesia was performed using propofol and/ or anesthetic gases. There are some cardiac surgery studies that confirmed higher blood cortisol levels in patients undergoing propofol anesthesia [15]. This effect was not observed in patients undergoing anesthesia with etomidate. Perhaps higher cortisol levels were maintained due to the way general anesthesia was performed.

In the Iribarren et al. study [11] a higher demand for inotropic drugs was found in the group experiencing relative adrenal insufficiency. This study showed the association of cortisol secretion in the morning after the first postoperative day and the total dose of dopamine and adrenaline. The relationship between lactate concentration on the $2^{\text {nd }}$ day and cortisol concentration on the day of surgery was also demonstrated. It seems that increased secretion of cortisol after cardiac surgery observed in patients with a higher lactate level may be associated with a more difficult postoperative course.

Mu et al. found a relationship between high plasma cortisol concentration on the first day after coronary artery bypass surgery and an increased risk of cognitive impairment in the early postoperative period. Patients with $690 \mathrm{nmol} / \mathrm{l}$ had a higher risk of post-operative cognitive impairment $(p<0.001)$ [16]. We observed a correlation between postoperative delirium and cortisol concentration on the $2^{\text {nd }}$ day after surgery.

The most interesting result was the increase in cortisol secretion with the age of operated patients. Cortisol is a willingly used marker of surgical stress, because its secretion is proportional and positively correlated with the magnitude of surgical stimulation $[17,18]$. There is a feedback mechanism between the brain and the secretion of glucocorticoid hormones. Under stress conditions, the brain promotes secretion of cortisol through the corticotropin hormone secreted by the hypothalamus. On the other hand, glucocorticosteroids induce a feedback mechanism by affecting specific receptors in the hypothalamus. In addition, the hippocampus plays an important role in suppressing the pituitary-hypothalamic-adrenal axis in response to stress, at least partially activating the glucocorticosteroid receptors in this region [19]. Glucocorticosteroid receptors in the hypothalamus are gradually lost in the process of normal aging. This results in the weakening of this negative feedback mechanism, which inhibits further secretion of corticosteroids [20]. Numerous studies indicate the existence of a strong correlation between elevated cortisol and hippocampal damage and/or loss of glucocorticoid receptors, both of which are associated with learning disabilities. Loss of glucocorticoid receptors and weakening of the feed- back mechanism makes the elderly more prone to chronic hypersecretion of corticosteroids and cognitive impairment after surgery. In patients after non-cardiologic procedures, circadian rhythm disorders have been demonstrated in the cortisol level and are associated with cognitive dysfunction in the early postoperative period [21]. The current study did not assess the cortisol secretion during the day, so it is impossible to identify potential disorders in the circadian rhythm of cortisol secretion.

The main limitation of this study is the small size of the examined group. Nevertheless, the aim of the study was to screen for cortisol secretion disorders in older patients after cardiac surgery.

The study was not randomized. The restrictive inclusion criteria in the study reduced the heterogeneity of the group.

\section{Conclusions}

A short Synacthen test allows one to predict secretion of cortisol after cardiac surgery. Greater secretion of cortisol after cardiac surgery could be associated with a more difficult postoperative course. There was no decrease in cortisol secretion with age. The role of cortisol in therapy remains important, and further studies are needed to assess its secretion in elderly patients in cardiac surgery.

\section{Acknowledgments}

The study was funded by financial resources for doctoral students of the Medical University of Silesia (Nr KNW2-K83/D/6/K).

\section{Disclosure}

The authors report no conflict of interest.

\section{References}

1. Vermes I, Beishuizen A, Hampsink RM, Haanen C. Dissociation of plasma adrenocorticotropin and cortisol levels in critically ill patients: possible role of endothelin and atrial natriuretic hormone. J Clin Endocrinol Metab 1995; 80: 1238-1242.

2. Marik PE, Zaloga GP. Adrenal insufficiency in the critically ill: a new look at an old problem. Chest 2002; 122: 1784-1796.

3. Cappabianca G, Rotunno C, de Luca Tupputi Schinosa L, Ranieri VM, Paparella $D$. Protective effects of steroids in cardiac surgery: a meta-analysis of randomized double-blind trials. J Cardiothorac Vasc Anesth 2011; 25: 156-165.

4. Henzen C, Kobza R, Schwaller-Protzmann B, Stulz P, Briner VA. Adrenal function during coronary artery bypass grafting. Eur J Endocrinol 2003; 148: 663-668.

5. Otte C, Hart S, Neylan TC, Marmar CR, Yaffe K, Mohr DC. A meta-analysis of cortisol response to challenge in human aging: importance of gender. Psychoneuroendocrinology 2005; 30: 80-91.

6. Lupien S, Lecours AR, Schwartz G, Sharma S, Hauger RL, Meaney MJ, Nair NPV. Longitudinal study of basal cortisol levels in healthy elderly subjects: evidence for subgroups. Neurobiol Aging 1996; 17: 95-105.

7. Salem M, Tainsh RE, Bromberg J, Loriaux DL, Chernow B. Perioperative glucocorticoid coverage. A reassessment 42 years after emergence of a problem. Ann Surg 1994; 219: 416-425.

8. Coursin DB, Wood KE. Corticosteroid supplementation for adrenal insufficiency. JAMA 2002; 287: 236-240.

9. Raja PV, Blumenthal JA, Doraiswamy PM. Cognitive deficits following coronary artery bypass grafting: prevalence, prognosis, and therapeutic strategies. CNS Spectr 2004; 9: 763-772. 
10. Annane D, Maxime V, Ibrahim F, Alvarez JC, Abe E, Boudou P. Diagnosis of adrenal insufficiency in severe sepsis and septic shock. Am J Respir Crit Care Med 2006; 174: 1319-1326.

11. Iribarren JL, Jiménez JJ, Hernández D, Lorenzo L, Brouard M, Milena A, Nora ML, Martinez R. Relative adrenal insufficiency and hemodynamic status in cardiopulmonary bypass surgery patients. A prospective cohort study. J Cardiothorac Surg 2010; 5: 26.

12. de Jong MFC, Beishuizen A, Spijkstra JJ, Groeneveld ABJ. Relative adrenal insufficiency as a predictor of disease severity, mortality, and beneficial effects of corticosteroid treatment in septic shock. Crit Care Med 2007; 35: 1896-1903.

13. Reves JG, Karp RB, Buttner EE, Tosone S, Smith LR, Samuelson PN, Kreusch GR, Oparil S. Neuronal and adrenomedullary catecholamine release in response to cardiopulmonary bypass in man. Circulation 1982; 66: 49-55.

14. Hoda MR, El-Achkar H, Schmitz E, Scheffold T, Vetter HO, De Simone R. Systemic stress hormone response in patients undergoing open heart surgery with or without cardiopulmonary bypass. Ann Thorac Surg 2006; 82: 2179-2186.

15. Kaushal RP, Vatal A, Pathak R. Effect of etomidate and propofol induction on hemodynamic and endocrine response in patients undergoing coronary artery bypass grafting/mitral valve and aortic valve replacement surgery on cardiopulmonary bypass. Ann Card Anaesth 2015; 18: 172-178.
16. Mu DL, Li LH, Wang DX, Li N, Shan GJ, Li J, Yu QJ, Shi CX. High postoperative serum cortisol level is associated with increased risk of cognitive dysfunction early after coronary artery bypass graft surgery: a prospective cohort study. PLoS One 2013; 8: e77637.

17. Chernow B. Hormonal responses to graded surgical stress. Arch Intern Med 1987; 147: 1273-1278.

18. Widmer IE, Puder JJ, König C, Pargger H, Zerkowski HR, Girard J, Müller B. Cortisol response in relation to the severity of stress and illness. J Clin Endocrinol Metab 2005; 90: 4579-4586.

19. Jacobson L, Sapolsky R. The role of the hippocampus in feedback regulation of the hypothalamic-pituitary-adrenocortical axis. Endocr Rev 1991; 12: 118-134.

20. Belanoff JK, Gross K, Yager A, Schatzberg AF. Corticosteroids and cognition. J Psychiatr Res 2001; 35: 27-45.

21. Rasmussen LS, O'Brien JT, Silverstein JH, Johnson TW, Siersma VD, Canet J, Jolles J, Hanning CD, Kuipers HM, Abildstrom H, Papaioannou A, Raeder J, YliHankala A, Sneyd JR, Munoz L, Moller JT; ISPOCD2 Investigators. Is peri-operative cortisol secretion related to post-operative cognitive dysfunction? Acta Anaesthesiol Scand 2005; 49: 1225-1231. 